\title{
Case study: Awareness of indigenous knowledge associated with traditional herbs for health and sustainable development
}

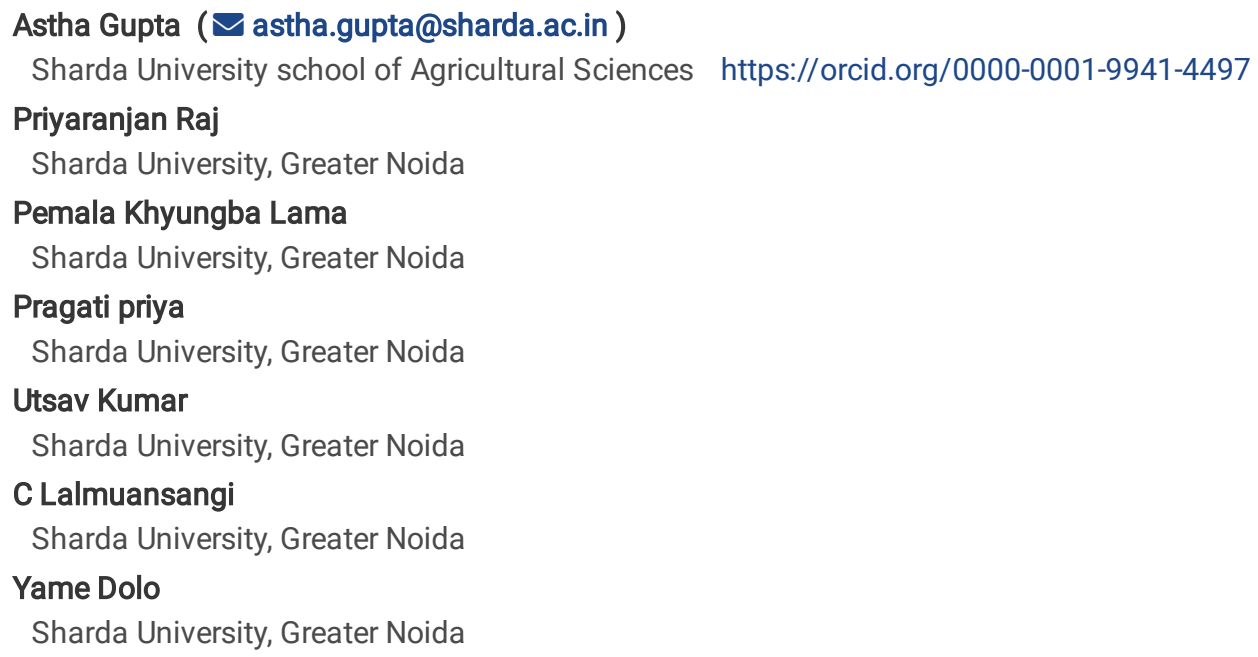

Keywords: Awareness, Conservation, Medicinal and antioxidant properties, Traditional herbs

Posted Date: August 31st, 2021

DOI: https://doi.org/10.21203/rs.3.rs-845816/v1

License: (c) (i) This work is licensed under a Creative Commons Attribution 4.0 International License. Read Full License 


\section{Abstract \\ Background}

Traditional herbs are renowned from very ancient time due to historical, mythologicaland medicinal significance. In present scenario, traditional herbs are "Necessity of the new era" because they are also effective for deadly coronavirus disease (COVID-19).

\section{Methods}

To explore to pre-existing knowledge of traditional herbs, we investigated good numbers of participants from different location and age group. Most of the participants belong from age group of 18-25 (79.4\%) followed by age group 26-30 (11.8\%). Remarkably, good number of female candidate (58.8\%) was actively involved as compared to male candidates (41.2\%). Maximum number of peoples (26.5\%) responded from Kathmandu (Nepal) and Mizoram, (India) followed by Nepalgunj (17.6\%, Nepal) and Uttar Pradesh (11.8\%, India).

\section{Results}

Interestingly, $82.4 \%$ peoples were aware about medicinal plants and $73.5 \%$ showed interest for learning. However, $64.7 \%$ and $35.3 \%$ peoples prefer medicinal herbs and pharmaceutical medicines respectively. Some participants explained that medicinal herbs are effective without side effects but very slow and are not helpful in emergencies. As data indicated $76.5 \%$ individuals were given the positive attention for medicinal plants farming.Data depicts that $82.4 \%$ individuals have been tried the medicinal herbs (turmeric, basil, giloy and aloe vera) in daily life and cured but $17.6 \%$ individuals were not cured after application. Besides, $11.8 \%$ peoples were allergic and rest of the $88.2 \%$ peoples was nonallergic to medicinal herbs and feel considerable positive effect (refresh, relax and glowing skin). Good number of the candidates was known to tulsi $(70.6 \%)$ and aloe vera (64.7\%). However, $14.7 \%$ peoples were unconvinced for medicinal herbs efficiency.

\section{Conclusion}

Traditional herbs are undervalued due to lack of knowledge/awareness and low availability in market. Therefore, present survey would be useful for society awarenessand daily consumption may improve the physical and mental health. In future, herbs farming would be good choice for extra income source and sustainable development in both rural and urban community.

\section{Background}

Traditional herbs are beneficial to treat the common ailments and act asremedy for cardiovascular disorders [1], sexual dysfunctions [2], diabetes [3], tummy trouble, headaches and irritation from bug bites due to presence of some polyphenolicand herbal compounds [4]. Traditional herbs or medicinal plants may be consumed in the form of pills, teas, essential oil and food garnishing. Thus, medicinal plants should be used in daily life due to notable health benefitsalongwith sleep improvement[5]. However, traditional medicines are a rich heritage of the Indiaand ministry (AYUSH: Ayurveda, Yoga, Unani, Sidha, and Homeopathy) has been released an advisory during the COVID-19 crisis for preventive health and immunity-boosting measures for self-care[6].

\section{Literature survey of traditional herbs}

There are number of medicinal herbs includes basil (ocimumbasilicum), aloe vera (Aloe barbadensis), garlic (Allium sativum), neem (Azadirachtaindica), fenugreek leaves (Trigonellafoenumgraecum) and amla (Phyllanthusemblica) that represents several properties includes anticancer, gastric ulceration, antioxidant, cytoprotective, immunomodulatory and cardiac stimulatory activities [7-12]. Mainstreaming of herbshas been found essential to detect medicinal properties and desired potential genotypes for enhancement the economic importance and agricultural improvement. Previous information would be worthwhile for basic understanding of medicinal herbs importance, its health benefits and their mode of action. Therefore, some medicinal plants have been surveyed to explore their significance and described below (Table 1 and Fig. 1). 
Table 1

List of medicinal herbs with their properties and common name used in India and Nepal.

\begin{tabular}{|c|c|c|c|c|c|c|}
\hline NAME & BOTANICAL NAME & FAMILY & $\begin{array}{l}\text { COMMON } \\
\text { NAME } \\
\text { (IN INDIA) }\end{array}$ & $\begin{array}{l}\text { COMMON } \\
\text { NAME } \\
\text { (IN NEPAL) }\end{array}$ & MEDICINAL VALUE & REFERENCES \\
\hline TULSI & $\begin{array}{l}\text { Ocimum } \\
\text { tenuiflorum }\end{array}$ & Lamiaceae & $\begin{array}{l}\text { Holy basil } \\
\text { (purple tulsi, } \\
\text { Krishna } \\
\text { tulsi) }\end{array}$ & tulsai & $\begin{array}{l}\text { Treatment of heart and } \\
\text { blood diseases, } \\
\text { leucoderma, strangury, } \\
\text { asthma, bronchitis, } \\
\text { lumbago and purulent } \\
\text { discharge of the ear, } \\
\text { diaphoretic, } \\
\text { antiperiodic, stimulant } \\
\text { and expectorant } \\
\text { properties. Helpful for } \\
\text { infantile cough, cold, } \\
\text { bronchitis, diarrhoea } \\
\text { and dysentery and } \\
\text { treat ringworm and } \\
\text { other skin diseases. } \\
\text { Antimicrobial, } \\
\text { pharmacological, any } \\
\text { therapeutic, nutritional } \\
\text { value, phytochemicals, } \\
\text { phytonutrients, Vitamin } \\
\text { A and C for cellular } \\
\text { protection. }\end{array}$ & $\begin{array}{l}{[11,27,28,} \\
29]\end{array}$ \\
\hline NEEM & Azadirachtaindica & Maliaceae & $\begin{array}{l}\text { Neem, Nim, } \\
\text { Margosa }\end{array}$ & Neem & $\begin{array}{l}\text { Inhibitory activity of } \\
\text { neem extracts on } \\
\text { Papain like protease } \\
\text { (PLpro) of the novel } \\
\text { coronavirus SARS-CoV- } \\
\text { 2, free radical } \\
\text { scavenging properties } \\
\text { due to rich source of } \\
\text { antioxidant, Neem } \\
\text { ingredient shows } \\
\text { effective role in the } \\
\text { management of cancer } \\
\text { through the regulation } \\
\text { of cell signaling } \\
\text { pathways, role as anti- } \\
\text { inflammatory via } \\
\text { regulation of pro- } \\
\text { inflammatory enzyme } \\
\text { activities including } \\
\text { cyclooxygenase (COX), } \\
\text { and lipoxygenase } \\
\text { (LOX) enzyme, } \\
\text { potential traditional } \\
\text { medicine for malaria } \\
\text { symptoms }\end{array}$ & [30] \\
\hline
\end{tabular}




\begin{tabular}{|c|c|c|c|c|c|c|}
\hline NAME & BOTANICAL NAME & FAMILY & $\begin{array}{l}\text { COMMON } \\
\text { NAME } \\
\text { (IN INDIA) }\end{array}$ & $\begin{array}{l}\text { COMMON } \\
\text { NAME } \\
\text { (IN NEPAL) }\end{array}$ & MEDICINAL VALUE & REFERENCES \\
\hline $\begin{array}{l}\text { ALOE } \\
\text { VERA }\end{array}$ & Aloe barbadensis & Asphodelaceae & $\begin{array}{l}\text { Indian aloe, } \\
\text { burn aloe, } \\
\text { Chinese aloe }\end{array}$ & GhyuKumari & $\begin{array}{l}\text { Treat burns and } \\
\text { sunburn, to aid wound } \\
\text { healing, fight against } \\
\text { cell aging, reinforces } \\
\text { the immune system } \\
\text { and improves blood } \\
\text { circulation., used in } \\
\text { Ayurvedic, } \\
\text { Homoeopathic and } \\
\text { Allopathic streams of } \\
\text { medicine, and not only } \\
\text { tribal com-munity but } \\
\text { also most of the } \\
\text { people for food and } \\
\text { medicine, numerous } \\
\text { vitamins, minerals, } \\
\text { enzymes, amino acids, } \\
\text { natural sugars and } \\
\text { other bioactive } \\
\text { compounds present in } \\
\text { plant leaves, emollient, } \\
\text { purgative, } \\
\text { antimicrobial, anti in- } \\
\text { flammatory, } \\
\text { antioxidant, } \\
\text { aphrodisiac, anti- } \\
\text { helmenthic, antifungal, } \\
\text { antiseptic and } \\
\text { cosmetic values for } \\
\text { health care. }\end{array}$ & {$[13,15]$} \\
\hline GARLIC & Allium Sativum & Amaryllidaceae & Garlic & Lasuna & $\begin{array}{l}\text { Antimicrobial, anti- } \\
\text { fungal, anti-thrombotic, } \\
\text { analgesic, anti- } \\
\text { asthmatic, antipyretic, } \\
\text { anti-hypertensive, anti- } \\
\text { coagulant, antioxidant, } \\
\text { and anti-cancer } \\
\text { properties, therapeutic } \\
\text { effects on oral } \\
\text { diseases, Inhibitory } \\
\text { activity of garlic } \\
\text { extract for } \\
\text { Lactobacillus } \\
\text { acidophilus, } \\
\text { Staphyloccocusaureus, } \\
\text { Nocardia asteroids, } \\
\text { pseudomonas } \\
\text { aeruginosa, } \\
\text { actinomycesviscosus, } \\
\text { veillonellaalcaligens } \\
\text { bacterial strains } \\
\text { reported. Combination } \\
\text { of garlic paste and } \\
\text { lime was used for } \\
\text { mouth sore, sore throat } \\
\text { and also can be used } \\
\text { in toothpaste to } \\
\text { prevent dental caries. }\end{array}$ & {$[31,32]$} \\
\hline
\end{tabular}




\begin{tabular}{|c|c|c|c|c|c|c|}
\hline NAME & BOTANICAL NAME & FAMILY & $\begin{array}{l}\text { COMMON } \\
\text { NAME } \\
\text { (IN INDIA) }\end{array}$ & $\begin{array}{l}\text { COMMON } \\
\text { NAME } \\
\text { (IN NEPAL) }\end{array}$ & MEDICINAL VALUE & REFERENCES \\
\hline $\begin{array}{l}\text { FENUGREEK } \\
\text { LEAVES }\end{array}$ & Trigonellafoenumgraecum & Fabaceae & Kasturimethi & Kasoorimethi & $\begin{array}{l}\text { Fenugreek seeds and } \\
\text { leaves are } \\
\text { anticholesterolemic, } \\
\text { anti-tumour, anti- } \\
\text { inflammatory, } \\
\text { carminative, } \\
\text { demulcent, } \\
\text { deobstruent, emollient, } \\
\text { expectorant, } \\
\text { galactagogue, } \\
\text { febrifuge, laxative, } \\
\text { hypoglycaemic, } \\
\text { restorative, parasiticide } \\
\text { and uterine tonic and } \\
\text { useful in burning } \\
\text { sensation, bone and } \\
\text { muscles, respiratory } \\
\text { system, } \\
\text { gastrointestinal } \\
\text { system, female } \\
\text { reproductive system, } \\
\text { cardio-vascular } \\
\text { system, endocrinology } \\
\text { and hepatic, beneficial } \\
\text { against numerous } \\
\text { diseases such as } \\
\text { cancer, } \\
\text { hypercholesterolemia, } \\
\text { diabetes and } \\
\text { inflammation. }\end{array}$ & {$[10,33]$} \\
\hline GILOY & Tinosporacordifolia & Menispermaceae & $\begin{array}{l}\text { Heart leaved } \\
\text { moon seed, } \\
\text { guduchi and } \\
\text { giloy }\end{array}$ & $\begin{array}{l}\text { Gurujpaani, } \\
\text { gurjo. }\end{array}$ & $\begin{array}{l}\text { Potential component } \\
\text { for the development of } \\
\text { biopharmaceutical } \\
\text { products, as tonic, } \\
\text { alterative, diuretic, and } \\
\text { aphrodisiac properties. } \\
\text { It is a febrifuge used in } \\
\text { malarial and chronic } \\
\text { fever, as liver tonic, } \\
\text { antispasmodic, } \\
\text { antidiabetic, anti- } \\
\text { arthritic, antiperiodic, } \\
\text { anti-inflammatory, } \\
\text { antioxidant, antistress, } \\
\text { anti-allergic, } \\
\text { antimalarial, } \\
\text { hepatoprotective, } \\
\text { antileprotic, } \\
\text { antineoplastic, and } \\
\text { immunomodulatory } \\
\text { activities. } \\
\text { Phytochemical } \\
\text { content: steroids, } \\
\text { alkaloids, diterpenoid } \\
\text { lactones, and } \\
\text { glycosides and } \\
\text { recommended in } \\
\text { diabetes, } \\
\text { stomachache, } \\
\text { jaundice, urinary } \\
\text { problems, skin } \\
\text { ailments, and } \\
\text { prolonged diarrhea and } \\
\text { dysentery. }\end{array}$ & {$[34,35]$} \\
\hline
\end{tabular}




\begin{tabular}{|c|c|c|c|c|c|c|}
\hline NAME & BOTANICAL NAME & FAMILY & $\begin{array}{l}\text { COMMON } \\
\text { NAME } \\
\text { (IN INDIA) }\end{array}$ & $\begin{array}{l}\text { COMMON } \\
\text { NAME } \\
\text { (IN NEPAL) }\end{array}$ & MEDICINAL VALUE & REFERENCES \\
\hline AMLA & Phyllanthusemblica & Euphorbiaceae & $\begin{array}{l}\text { Indian } \\
\text { gooseberry }\end{array}$ & Amala & $\begin{array}{l}\text { Regulates anti-aging, } \\
\text { antidiabetic, } \\
\text { anticancer, antipyretic, } \\
\text { and analgesic } \\
\text { activities, } \\
\text { hepatoprotective and } \\
\text { cardioprotective } \\
\text { properties and } \\
\text { immunomodulatory } \\
\text { effects, reduction. } \\
\text { Phenolic acids, sinapic } \\
\text { and ferulic acids } \\
\text { present in amla. } \\
\text { Remedy for lightening } \\
\text { skin color, skin } \\
\text { elasticity and } \\
\text { hydration, skin wrinkle } \\
\text { and dental-related } \\
\text { problems, improve hair } \\
\text { growth and enhance } \\
\text { memory power. }\end{array}$ & {$[12,36]$} \\
\hline
\end{tabular}

\section{Aloe vera (Aloe barbadensis)}

Aloe veraL. (Syn: Aloe barbadensisMiller; Hindi: Ghikanvar) belongs to family Liliaceae (sub-

familyoftheAsphodelaceae)andalsoknownas"GhrithKumari".Itismostimportantmedicinal plants which have several properties comprise anticancer, gastric ulceration, antioxidant, cytoprotective, immune-modulatory and cardiac stimulatory activities [7, 13]. Additionally, particular genotype of Aloe vera L. is considered as a vegetable and good source of food also due to presence of biologically active compounds for example: anthraquinones, carbohydrates, amino acids, organic acids, active enzymes, vitamins, minerals and microelements [14]. However, Aloe verahas been considered as commercial crop due to its wide range application in medicinal, pharmaceutical, cosmetic and food industries. Moreover, high medicinal value compounds of Aloe Vera like Aloin, Aloe emodin, Aloe bitter and Aloe lectin contributes various health benefits. Furthermore, inflorescence of Aloe Vera exhibited antifungal activity and plant growth-promoting potential [15].

\section{Basil (Ocimum basilicum)}

Holy basil, commonly referred as tulsi or "The Queen of Herbs" has beenexplored in India [16]. A common herb contains polysaccharides, naphtha, steroids, flavone, coumarins, vitamins and minerals (vitamin K, iron and manganese) used to garnish salads, pasta and many other meals to add delicious flavor that helps to metabolize different compounds in body [11]. However, polysaccharides is one of the most chief therapeutics component of basil that exhibits biological activities and pharmacological applications, for instance antitumor activity, anti-aging activity, antioxidant activity, immunity enhancement effect, antibacterial effect, hypolipidemic and anti-atherosclerotic effects, treatment of diabetes mellitus etc. [11]. However bioactive phenolic compounds have been evaluated in leaves and flowers of green and purple basil [17]. All parts of plants (leaves, flowers and corollas) of Italiano Classico (green), Red Rubin and Dark Opal (purple) contains approximately 17 polyphenolic acids and 18 flavonoids that identified through LC-ESI-MS/MS analysis [17]. Further they reported that these three basal varieties have been characterized forrosmarinic acid, numerous members of the salvianolic acid and new biochemicalinformation.

\section{Garlic (Allium sativum)}

Garlic is extensively consumed and widespread spice with a specific "aroma" which has several bioactive components such as organo-sulfur compounds, saponins and polyphenols, rich in vitamins and minerals [9]. Secondary metabolites and bioactive compounds of garlic involved in antimicrobial activities, neuro- and renal-protection, antioxidant, anti-inflammatory, lipid-lowering properties and contributes for health improvement for example: cancer, blood pressure, diabetes, cardiovascular and metabolic disorders [8, 9]. Recently Zhang et al. (2020) explored the phytochemicals of garlic andcharacterized as promising applicants for treatment of cancer therapy [18]. In addition, garlic exhibits good retention capability of vitamin $\mathrm{C}$ as compared to aluminium packed samples as tested with garlic mashed potatoes in a microwave-assisted thermal sterilization (MATS) system [19].

\section{Conservation strategies, Cultivation practice and Sustainable use}

Worldwide, medicinal plant resources are being harvested in good proportion basically from wild populations which increased approximately 8-15\% per year in North America, Europe, and Asia [20]. Traditional knowledge and medicinal plants may be conserved through in situ and ex 
situ method. However, natural reserves and wild nurseries are more appropriate to maintain the original and potential properties of herbs/plants in their natural habitats. Botanic gardens and seed banks are imperative models for ex-situ conservation and future cultivation. Understanding of geographic location, availability of natural remedies, and practice of traditional knowledge and biological characteristics of particular herb is very important to conserve among local communities [21].

Wild and cultivated individuals of specific medicinal plant behave differently for any disease due to variation in biologically active compounds and ecological conditions. However, depth knowledge of cultivation practice is also desirable for herbs conservation like appropriate amount of water, temperature, light, nutrients and other factors that regulated the several metabolic processes through biochemical pathways. There should be proper guidelines/manuals for medicinal plants cultivation and application of new environment friendly techniques that would be useful for growers or small farmers infuture.

Different parts (like root, stem and leaf) of the herbs or medicinal plants plays specific role and useful for antitumor activity, anti-aging activity, antioxidant activity, immunity enhancement, antibacterial properties etc. Therefore, combination of integrated approach of medicinal herbswith combinations of numerous active compounds will be more potential resource for treatment of disease/disorder. In future, large scale production of natural potentially active compounds and high-value secondary metabolites may be possible through tissue culture (plant cell and transgenic hairy root culture), micro-propagation and fermentation of medicinal plants [22, 23]. Marker assisted breeding is also very promising approach for medicinal plant improvement at genetic level within short period of time. In the same time, completely dependency on pharmaceutical medicines will be diluted and community will be more focus on the traditional medicines to live the healthy life without any side- effects.

Accessibility of natural remedies and traditional knowledge practice may promote the use of medicinal herbs among local communities and society. However, Ayurveda medicine/ traditional herbs are in extinction stage which may be due to insufficient knowledge, urbanization, less interest and climatic conditions. Medicinal plants have considerable health benefits based on previous literature. Further, assessment of preexisting society awareness survey would be helpful to find out the gap in community based on collected data and individualknowledge related to importance of traditional herbs, ethno-medicinal properties, cultivation practices, their interest and responsiveness. Though, prevalent concern of present survey is to improve the traditional knowledge and inculcate the seed of motivation for its conservation.

\section{Methods}

\section{Sample size and their location}

For present survey, participants or representatives were investigated from two sites comprises India and Nepal (Fig. 2) and total sample size was 34 individuals. In brief, participants were belonging from different location and community includes Delhi, Uttar Pradesh, Rajasthan, Mizoram, Nagaland, Bihar from India and Kathmandu, Nepalgunj, Jhapa from Nepal accordingly. However, India and Nepalincludes 18 and 16 representatives respectively.

\section{Data Collection And Evaluation}

For collection of data, questionnaire was created and divided in two sections which contain total 40 questions (Table 2).Total 40 questions were further categorized in to multiple choice questions (section A) and descriptive/short questions (Section B).Out of that 28 questions (question number: 1-28) were multiple choice questions and rest of descriptive questions (question number: 29-40) to record the individual view, pre-existing knowledge and understanding regarding uses and application of medicinal herbs/ plants in their local community. Same questionnaire was prepared in both mode that includes online (google form) as well as in offline mode (data physically scored onsite) for data collection.Present study was based on different criteria, For example: diverse range of age, gender and locality. Individuals were chosen randomly that represents single member of individual family.Questions were in easy language (English) for direct discussion related to traditional herbs awareness, earlierunderstanding in community and daily life uses.Data was scored for all nominatedparticipant/ individual.Further data was compiled based on received responses for respective questions and examined accordingly. Data was evaluated and bar charts were prepared forqualitative data analysis using MS-excel. 
Questionnaire of survey

\begin{tabular}{|c|c|c|c|c|}
\hline S/NO & Multiple Choice Question (Section A) & Option A & Option B & Option C \\
\hline 1 & What do you prefer the most? & $\begin{array}{l}\text { Medicinal } \\
\text { herb }\end{array}$ & $\begin{array}{l}\text { Pharmaceutical } \\
\text { medicine }\end{array}$ & \\
\hline 2 & $\begin{array}{l}\text { Do you think people would recommend one another to use medicinal herbs } \\
\text { for any cause or disease? }\end{array}$ & Yes & No & Maybe \\
\hline 3 & What is the reason for less use of medicinal herbs? & $\begin{array}{l}\text { Lack of } \\
\text { awareness }\end{array}$ & $\begin{array}{l}\text { Decreasing } \\
\text { interest }\end{array}$ & $\begin{array}{l}\text { Decrease in study } \\
\text { of medicinal herb } \\
\text { practice }\end{array}$ \\
\hline 4 & Would you be interested to learn about medicinal herbs? & Yes & No & Maybe \\
\hline 5 & Do you think there is profit on doing farming on medicinal herbs? & Yes & No & Maybe \\
\hline 6 & Are you aware about some medicinal herbs which are found around you? & Yes & No & \\
\hline 7 & Would you prefer home remedies? & Yes & No & \\
\hline 8 & Did you know aloe-vera is the king of medicinal plants? & Yes & No & \\
\hline 9 & Did you know Tulsi is known as mother medicine of nature? & Yes & No & \\
\hline 10 & Do you think medicinal herbs are efficient? & Yes & No & \\
\hline 11 & Do you consider cannabis as medicinal herb? & Yes & No & \\
\hline 12 & Have you been cured from medicinal herbs? & Yes & No & \\
\hline 13 & Do you have any allergies with medicinal herbs? & Yes & No & \\
\hline 14 & $\begin{array}{l}\text { Did you know medicinal herbs play the big role in changing the state of } \\
\text { one's mind? }\end{array}$ & Yes & No & \\
\hline 15 & Do you prefer single or mix of medicinal herbs? & Single & Mix & \\
\hline 16 & $\begin{array}{l}\text { Did you know Tulsi is used to cure cough, cold, bronchitis and loss of } \\
\text { appetite? }\end{array}$ & Yes & No & \\
\hline 17 & $\begin{array}{l}\text { Do you believe peppermint tea helps relax tension and could lower blood } \\
\text { pressure? }\end{array}$ & Yes & No & \\
\hline 18 & $\begin{array}{l}\text { Do you think parsley have significant amount of essential vitamins like A } \\
\text { and C? }\end{array}$ & Yes & No & Maybe \\
\hline 19 & Do you watch KrishiDarshan? & Yes & No & \\
\hline 20 & $\begin{array}{l}\text { Do you believe that the ancient scholar only believed that herbs are only } \\
\text { solutions to cure a number of health related problems and diseases? }\end{array}$ & Yes & No & Maybe \\
\hline 21 & $\begin{array}{l}\text { Which one do you think is more effective for constipation, acne and poor } \\
\text { body immunity? }\end{array}$ & Aloe-vera & $\begin{array}{l}\text { Pharmaceutical } \\
\text { medicine }\end{array}$ & \\
\hline 22 & $\begin{array}{l}\text { Have you heard about the treatment with medicinal plants which is } \\
\text { considered very safe with no side effects of it? }\end{array}$ & Yes & No & \\
\hline 23 & $\begin{array}{l}\text { Did you know herbs such as black pepper, red clover, cinnamon are used to } \\
\text { heal wounds, sore and boils? }\end{array}$ & Yes & No & \\
\hline 24 & Do you know any research done on any medicinal plants? & Yes & No & \\
\hline 25 & Which part of the medicinal plants do you think are mostly used? & Root & Stem & Leaves \\
\hline 26 & Do you think not just humans but animals also depend on medicinal herbs? & Yes & No & Unsure \\
\hline 27 & $\begin{array}{l}\text { Do you think the mixture of different medicinal herbs is better than those } \\
\text { manufactured medicine? }\end{array}$ & Yes & No & Maybe \\
\hline 28 & What is the frequency in the use of medicinal herbs? & Daily & Weekly & As per needed \\
\hline
\end{tabular}




\section{S/NO Multiple Choice Question (Section A)}

Option A

Option B

Option C

29. Cannabis is considered illegal in our countries where it is legal in some countries and are in use or are in practice for the healing process. What is your opinion, should it be legalized in our country as well?

30. Do you think most of the medicinal herbs are being exploited on the verge of extinction? If yes, what can be done to conserve them?

31. Considering the COVID-19 situation, what medicinal herbs do you recommend to increase your immunity power?

32. What is your opinion on medicinal plants?

33. Have you tried using turmeric as a home remedy to heal cut and wounds? If yes, do you think it's effective?

34. Have you tried Ginseng which is a popular herbal supplement, well known for its energy boosting properties? If yes, can you tell the benefits?

35. What are the medicinal herbs that you use in your day to day life?

36. What do you think are the reasons for the medicinal herbs being so underrated?

37. What do you think about the people who believe in pharmaceutical medicines over medicinal herbs?

38. What do you think about the people who are into medicinal herbs and don't believe in vaccines?

39. What made you think medicinal herbs have put a change in your day to day life?(If in use please elaborate)

40. Do you think you can earn a living by growing medicinal herbs? If yes, why?

\section{Result}

All the responses/answers of participants were collected and analyzed section wise (Section A and section B). Further, data represented in the form of bar diagram that indicates the multiple choice question/section-A in Fig. 3 (age, gender and percentage of peoples with their location), Fig. 4 (question number: 1-16) and Fig. 5 (question number: 17-28). Maximum number of participants (26.5\%) responded from Kathmandu (Nepal) and Mizoram, (India) followed by Nepalgunj (17.6\%, Nepal) and Uttar Pradesh (11.8\%, India) (Fig. 3: A).However, participants belong to age group of 18-25 (79.4\%) were more actively contributed followed by age group 26-30 (11.8\%) for present survey(Fig. 3: B). Interestingly, good number of female candidate (58.8\%) was involved as compared to malecandidates (41.2\%) in the assessment (Fig. 3: C). Based on survey results, most of peoples prefer medicinal herbs (64.7\%) over the pharmaceutical medicines and believes that medicinal herbs are useful for several diseases (Fig. 4:1,2). In contrast to that most of the individuals (58.8\%) think medicinal herbs are not in very much use due to lack of awareness, less interest and poor study of traditional herbs or medicinal plants (Fig. 4: 3). However, $26.4 \%$ individuals/participates were not interested to learn and discuss about medicinal plants (Fig. 4:4). Moreover, 76.5\% individuals were given the positive attention for medicinal plants farming and $20.6 \%$ individuals were confused for their practices (Fig. 4: 5). Approximately 17.6\% peoples were not aware about medicinal plants that are growing near them and interestingly, 82.4\% peoples were aware about medicinal plants and showed interest for farming (Fig. 4: 6 and 7).

Further, we discussed about home remedies and associated plants (aloe-vera, tulsi and cannabis) to check their prior knowledge and found that $67.6 \%$ peoples were interested to use medicinal plants as home remedies and rest of individuals were not interested or worried in terms of side effects. Good number of the candidates was known to tulsi and aloe vera that was $70.6 \%$ and $64.7 \%$ respectively (Fig. 4: 8, 9). However, $14.7 \%$ peoples were doubtful for medicinal herbs efficiency (Fig. 4: 10). Data depicts that $82.4 \%$ individuals have been tried the medicinal herbs and cured but $17.6 \%$ individuals were not cured after application (Fig. 4: 12). Besides, $11.8 \%$ peoples were allergic and rest of the $88.2 \%$ peoples was non-allergic to medicinal herbs (Fig. 4: 13). Nevertheless, $67.6 \%$ peoples believe that medicinal herbs may alter the state of mind (Fig. 4: 14). Combination of medicinal herbs was also explored by community and $58.8 \%$ peoples prefer the mixture of herbs (Fig. $4: 15$ ). Approximately, $80.6 \%$ and $63.3 \%$ peoples were aware for medicinal properties of tulsi and peppermint accordingly that cure or regulates cough, cold, appetite, wounds healing, tension relaxation and blood pressure (Fig. 4: 16; Fig. 5: 17). Nutritional properties of parsley were not in the notice of $32.3 \%$ individuals (Fig. 5: 18). We discussed about Krishi Darshan that is an Indian television program which provides information in agriculture, herbs, important plants and cultivation practices. As result interprets, $93.5 \%$ individuals had very less interest in such kind of programs and did not watch Krishi Darshan (Fig. 5: 19). Though, 54.8\% individuals were familiar with ancient history of medicine and their uses to solve the several diseases but $45.1 \%$ individuals were not mindful/interested (Fig. 5: 20). Some of the herbs were liked and accepted by several peoples for example black pepper, cinnamon and aloe vera with consideration of no side effects over pharmaceutical medicines. Unfortunately, $51.6 \%$ peoples were not aware in terms of medicinal plants research (Fig. 5: 24). Likewise, majority of peoples (71\%) consider only leaves may be fruitful as medicinal herbs (Fig. 5: 25). However, $80.6 \%$ candidate's believes that medicinal herbs are not only supports human health but also cure some animal's diseases (Fig. 5: 26). Appropriate combination of different herbs may be helpful as compared to manufactured medicines as large group of individuals (67.7\%) stated but rest of the individuals was either doubtful or were not very much 
clear(Fig. 5: 27). When we talked about the uses of medicinal herbs in daily life, $87.1 \%$ individuals prefer as per needed and only $9.7 \%$ use in the form of green tea or food material as daily healthy diet (Fig. 5: 28).

In continuation to previous multiple choice question (question number:1-28), moved to collect and analyzedthe data of descriptive questions (question number: 29-40). Surprisingly, we received several views, opinion and arguments for same question irrespective of location, age and gender. Next assessment was recorded in relation to cannabisrelease in country due to its medicinal significance and controversy. Some of the individuals from Nepal were in favor of legalized and others were worried about its negative impacts on health and society due to less selfcontrol and high dose consumption. Similarly, some of the statements of Indian individuals were in the motion and some against motion (Question number 29). Statements were recorded and are following "Legalizing cannabis might make the production more open and might even decrease the illegal trading", "Legalized but under prescription and some restrictions", "Legalized with proper law implementation towards its farming due to its health benefits (fight against cancer, cure diseases and also reduce weight), it may help the medicine industry as well as country's income".In contrast to that some statements were not in favor that includes "Cannabis should be illegalized in countries because addiction of cannabis will not have any good results in society, it may lead to development of mental health problems, anxiety, and depression". Also, it may alter the brain development in adolescent. A participant raise the considerable point that non-harmful species/ variety of cannabis provides health benefits to the consumer but unknown variety may cause serious side effects and will be injurious due to psychoactive drug effect.

In relation to conservation of medicinal herbs, people have strong substantial opinion and suggested for manuals and awareness programs to grow these herbs at home;therefore, their farming and cultivation will be easy (Question number 30). Further they point out the conservation of medicinal herbs at their native place and botanical gardens of society and community. More and more knowledge and skill need to cultivate and special herbs farming schemes, incentives and plans should be launched from local government to promote it.Some of the direct statements of individuals include "Despite the existence of various sets of recommendations for the conservation and sustainable use of medicinal plants, only a small portion of these have achieved. Adequate protection of medicinal plant resources needed through conventional or modern conservation methods in natural reserves or botanic gardens". According to opinion of one aware and knowledgeable individual "Most of the medicinal herbs are being exploited on the verse of extinct and the conservation of medicinal plants may be accomplished by the ex-situ method i.e. outside natural habitat by cultivating and maintaining plants in botanic gardens, parks, other suitable sites, and through long term preservation of plant propagules in gene banks (seed bank, pollen bank, DNA libraries, etc.)

Considering the current COVID-19 situation, people recommended some medicinal herbs or different parts of plants with combination of complementary components to increase the immunity power includes gurjelato, aduwa, besar, tulsi, neem, jwano, wheatgrass, turmeric with milk or honey (Question number 31).All the participants given their honest review for medicinal plants uses and most of the participants were agreed to prefer medicinal plants due to minimum side effects, low cost, environmental friendly, reliable, numerous health benefits and immunity booster and also good for cold and flu, stress reliever and involve in better digestion. In contrast to this some participants had not prefer traditional/ medicinal herbs due to partial satisfaction and trust over pharmaceuticals medicines and given such statements like "medicinal herbs are good, but not for emergencies"; "It may be effective but overall performance is slow" (Question number 32 and 33 ).

Most of the candidates has been explored turmeric and applied as home remedy to recover the small cuts and wounds and were found to be satisfied with the effective healing power (Question number 34). Some of the candidates said that "Dabbing a generous amount of turmeric powder on a fresh cut will help to stop the oozing of blood and also prevent infections"; "turmeric is very good home remedy not only to heals the wounds and cuts but also it helps us from cough and colds". Most of the candidates were not tried and aware about Ginseng which is a popular herbal supplement and very few individuals were utilized to boost the immunity. Ginseng or Ashwagandha considered as traditional medicine for their valuable parts like roots and orange-red fruit components.

In daily life, frequency of aloe vera, tulsi, ginger, garlic, clove and turmeric was high as compared to rest of the herbs includes lemongrass, ashwagandha, tea tree, mint, black pepper, cinnamon, cardamom, giloy, green tea, gurjo, harrop, ghodethapre, amala (Question number 35). In continuation, medicinal herbs are undervalued due to lack of knowledge/awareness, slow recovery process and low availability in market. According to data evaluation (Question number 36 and 37), the choice of pharmaceutical and herbal medicines depends on several factors that are following "how a person's body reacts to it"; "pharmaceutical medicines may provide instant cure or may seem effective for a while, but may not be good in a long run"; "Just believe in the modern science and technology so prefer pharmaceutical medicines"; "Pharmaceutical medicines represents right compositions and scientifically proven so people strongly believes". Further, most of the participants stated (Question number 38) that medicinal herbs are effective but not explored yet in relation to COVID-19. Therefore peoples believe that depth research and trails of traditional medicines has been needed by using large population size of different regions. Standardization of traditional medicines would be required to identify the effective and appropriate formulation (scientific combinations) to test and recover from COVID-19. Although, vaccines are immediate relief so we should prefer vaccination in urgent basis. During data recording, we found that in one hand some of the individuals were not interested or explored traditional medicines for daily life use. In other hand good number of candidates consumed 
the herbs in daily life and feel considerable differences (like relax, refreshing and glowing skin) with the daily use of aloe vera, green tea, tulsi tea, aduwa, lemon, ghiukwari (Question number 39).They quote as "Healthy life style change with traditional medicines."

Further we asked about medicinal herbs farming and agribusiness to evaluate their mindset.Participants said that they are interested due to high demand of medicinal herbs in future as most of the peoples are focusing and moving to live a healthier and more natural lifestyle. Some of the direct answers of participants include thefollowing statements (Question number 40):

\section{Statement 1}

This profitable business is perfect for someone wanting to make extra money, spend more time outdoors, and have fun doing it. It's really quite easy and you can be on your way to big profits in the herbs business before you know it. You can also create awareness to more people how to live a healthier lifestyle by using more of medicinal herbs.

Statement 2: Yes! People have known about the deeds of medicinal herbs in present COVID-19 situation and they have been searching for it like crazy.So yes herbs farming would be a promising business for extra income source depending on cultivating area and particular agro-climatic conditions.

\section{Statement 3}

Yes! Nepal is already good for medical herbs production. The lacking things are proper awareness and the established market. If these two things will be addressed, a profitable living can be achieved by growing medicinal herbs in an increasing trend of global context.

\section{Statement 4}

Yes! People are getting exposed to medicinal herbs and their importance with application. Therefore,local to global medicinal market may establish slowly due to requirement of herbal compounds for medicine preparation and we may earn a living.

\section{Discussion}

Large number of individuals (79.4\%) concludes that lack of awareness is the major cause for less consumption of medicinal herbs.In the Indian mythology, tulsi plant situated in the very important place "Tulsi Mata/ The Queen of Herbs"[16] and use for worship of almighty God. However,approximately $29.4 \%$ peoples were not consciousfor herbs that show the lack of awareness, bonding and association from religion and ancient history of India. This is key points to understand "why peoples do not prefer home remedies". One of the explanation,peoplehas not read the IndianVedas in which medicinal properties of these herbs were mentioned by Rishi-Muni and great yogis. Interestingly, some of the research groups are trying to enriching the knowledge of ayurveda from Indian medicinal herbs through Machine Learning Approach [24]. However, $58.8 \%$ female participants responded and $79.4 \%$ responses were belonging to $18-25$ agegroup. This data indicates the active youth and female contribution which will be helpful to build educated and awareness society and community.

Number of herbs are using in Ayurveda, dentistry and several field of medicines and against COVID-19 also therefore considered as "Need of the new era" $[25,26]$. Most of the people were mindful about gurjelato, aduwa, besar, tulsi, neem, jwano, wheatgrass, turmeric, garlic, ashwagandha, clove, mint, black pepper, cinnamon, cardamom, giloy, green tea, gurjo, harrop, ghodethapre, amala as medicinal herb as medicine. However medicinal properties of these herbs already reported in literature (and table.Good number of individuals are using herbs as tea or food ingredients in daily life and feel considerable differences in terms of glowing skin, relax, refreshing, stress relieving, wound healing due to numerous features like antimicrobial,anticancer, gastric ulceration, antioxidant, cytoprotective, immune-modulatory and cardiac stimulatory activities $[7-9,11]$.

Therefore, most of the participants stated that suitable awareness programs are required to elevate the awareness of society in both Nepal and India. Further, conservation and cultivation of these traditional medicines should be start at local places to enhance the livelihood and source of extra income. Peoples were interested to prefer medicinal herbs over pharmaceuticals medicines but they were worried due to slow healing process and found not suitable for emergency purpose. Although, AYUSH (Indian ministry) recommend the traditional herbs not only for bacterial and fungal diseases but also for viral infection of COVID-19 [6].Further details are required on large human population of different location to identify the accurate composition and formulation (amount and combinations of single or multiple herbs).

\section{Conclusion}

Small group of participants was aware about medicinal herbs/ plants with theiruses.According to data, medicinal plants will be the good approach to treat the diseases. Medicinal herbs may alter the state of mind due to antioxidant properties. After investigation, it was observed that society is aware for giloy as medicinal plant because, giloy, turmeric and basil is very promising and potential source against COVID-19 and 
other diseases.Very few people have knowledge of conservation strategy and sustainable use of medicinal plants. Aloe vera has been using extensively for beauty purpose due to its medical properties. Therefore, first of all proper awareness programs are needed in society with distribution of proper booklet/manual indicates its medicinal and nutritional properties. In future, herbs farming may come in trends and individual person may grow at home, balcony or small area. This approach or society improvement programs will increase the livelihood, extra income source, aesthetic beauty and healthy life style. Previous findings explained conservation and sustainable use of medicinal plant. Although, in-situ and ex-situ method would be promising conservation strategies along with good cultivation practices for management and sustainable use of medicinal plant resources. In addition to that modern biotechnical approaches (e.g. tissue culture, micro propagation, synthetic seed technology and molecular marker-based approaches) would be more fruitful to improve the productivity and potency of medicinal plants.

\section{Abbreviations}

AYUSH: Ayurveda, Yoga, Unani, Sidha and Homeopathy; COVID-19: Corona Virus Disease-2019

\section{Declarations}

\section{Acknowledgements}

We are grateful to the participants for facilitating our survey through their contribution in answering the questionnaires. This research work was supported by Sharda University, Greater Noida. The authors are thankful to the Prof. H. S. Gaur, Dean, School of agricultural sciences, Sharda University, Greater Noida for support and continuous motivation.

\section{Author contributions}

The experiment was designed by AG, PR and PKL. Survey was conducted by PR, PKL,UK, CL,YD and literature was compiled by PP and AG. Data analysis and manuscript prepared by AG. All the authors have read and approved the final manuscript.

\section{Funding}

The present research has not received any grants from funding agencies.

\section{Availability of data and materials}

The data generated in the present study are available from the corresponding author on reasonable request.

\section{Ethics approval and consent to participate}

Particular ethical approval was not necessary since our survey did not involve any plant collection from individual community. There was only asking questions and interviewing them to evaluate the awareness of traditional herbs with their consent.

\section{Consent for publication}

Not applicable

\section{Competing interest}

The authors declare that they have no conflict of Interest.

\section{Author details}

All the authors (Astha Gupta, Priyaranjan Raj, Pemala Khyungba Lama,Pragati priya, Utsav Kumar, C Lalmuansangi, Yame Dolo) affiliated from School of Agricultural Sciences, Sharda University, Greater Noida-201310, India.

\section{References}

1. Rastogi S, Pandey MM, Rawat AKS. Traditional herbs: a remedy for cardiovascular disorders. Phytomedicine. 2016;23(11):1082-9. https://doi.org/10.1016/j.phymed.2015.10.012.

2. Adimoelja A. Phytochemicals and the breakthrough of traditional herbs in the management of sexual dysfunctions. Int $\mathrm{J}$ of androl. 2000;23(S2):82-4. https://doi.org/10.1046/j.1365-2605.2000.00020.x. 
3. Joseph B, Jini D. Insight into the hypoglycaemic effect of traditional Indian herbs used in the treatment of diabetes. Res J Med Plant. 2011;5(4):352-76. https://doi.org/10.3923/rjmp.2011.352.376.

4. Kulig D, Matysiak M, Baldovská S, Štefániková J, Maruniaková N, Mňahončáková E, Árvay J, Galbav D, Kolesárová A. Screening of polyphenolic compounds from traditional medicinal herbs. J of Microbio, Biotechnol and Food Sci. 2021; 2021 : $487-491$.

https://doi.org/10.15414/jmbfs.2019.9.special.487-491.

5. Bruni O, Ferini-Strambi L, Giacomoni E, Pellegrino P. Herbal remedies and their possible effect on the GABAergic system and sleep. Nutrients. 2021;13(2):530. https://doi.org/10.3390/nu13020530.

6. Gupta PK, Sonewane K, Rajan M, Patil NJ, Agrawal T, Banerjee ER, Chauhan NS, Kumar A. Scientific rationale of Indian AYUSH Ministry advisory for COVID-19 prevention, prophylaxis, and immunomodulation. Adv Tradit Med. 2021; 1-25. https://doi.org/10.1007/s13596-02100574-7.

7. Ramachandraiahgari RMY, Somesula SR, Adi PJ, Mannur IS, Enamala M, Matcha B. Protective role of ethanolic extract of Aloe vera antioxidant properties on liver and kidney of streptozotocin-induced diabetic rats. Dig J Nanomater Biostructures. 2012;7(1):175-84. https://chalcogen.ro/175_Yeggnisetty.pdf.

8. Ansary J, Forbes-Hernández TY, Gil E, Cianciosi D, Zhang J, Elexpuru-Zabaleta M, Simal-Gandara J, Giampieri F, Battino M. Potential Health Benefit of Garlic Based on Human Intervention Studies: A Brief Overview. Antioxidants. 2020;9(7):619. https://doi.org/10.3390/antiox9070619.

9. Netzel ME. Garlic: Much More Than a Common Spice. 2020. https://doi.org/10.3390/foods9111544.

10. Sun W, Shahrajabian $\mathrm{MH}$, Cheng Q. Fenugreek cultivation with emphasis on historical aspects and its uses in traditional medicine and modern pharmaceutical science. Mini-Rev Med Chem. 2020;21(6):724-30. https://doi.org/10.2174/1389557520666201127104907.

11. Zhan Y, An X, Wang S, Sun M, Zhou H. Basil polysaccharides: A review on extraction, bioactivities and pharmacological applications. Bio org Med Chem. 2020;28(1):115179. https://doi.org/10.1016/j.bmc.2019.115179.

12. Chaikul P, Kanlayavattanakul M, Somkumnerd J, Lourith N. Phyllanthusemblica. L.(amla) branch: A safe and effective ingredient against skin aging. J tradit complement med. 2021. https://doi.org/10.1016/j.jtcme.2021.02.004.

13. Jadhav AS, Patil OA, Kadam SV, Bhutkar MA. Review on Aloe vera is used in medicinal plant. Asian J Res Pharm Sci. 2020;10(1):26-30. http://dx.doi.org/10.5958/2231-5659.2020.00006.5.

14. Kumar S, Yadav M, Yadav A, Yadav JP. Molecular assessment of genetic diversity in Indian accessions of Aloe vera using SSR marker. Int J Pharm Pharm Sci. 2015;7(12):149-54.

15. Chowdhary K, Sharma S. Plant Growth Promotion and Biocontrol Potential of Fungal Endophytes in the Inflorescence of Aloe vera L. Proc Natl Acad Sci Acad Sci India Sect B Biol Sci. 2020;90(5):1045-55. https://doi.org/10.1007/s40011-020-01173-3.

16. Vij D, Gupta S. Ocimum sanctum: The Queen of Herbs. Educational Research (IJMCER). 2021;3(2):49-52.

17. Prinsi B, Morgutti S, Negrini N, Faoro F, Espen L. Insight into composition of bioactive phenolic compounds in leaves and flowers of green and purple Basil. Plants. 2020;9(1):22. https://doi.org/10.3390/plants9010022.

18. Zhang Y, Liu X, Ruan J, Zhuang X, Zhang X, Li Z. Phytochemicals of garlic: Promising candidates for cancer therapy. Biomed Pharmacother. 2020;123:109730. https://doi.org/10.1016/j.biopha.2019.109730.

19. Patel J, Parhi A, Al-Ghamdi S, Sonar CR, Mattinson DS, Tang J, Yang T, Sablani SS. Stability of vitamin C, color, and garlic aroma of garlic mashed potatoes in polymer packages processed with microwave-assisted thermal sterilization technology. J of Food Sci. 2020;85(9):2843-51. https://doi.org/10.1111/1750-3841.15366.

20. Chen SL, Yu H, Luo HM, Wu Q, Li CF, Steinmetz A. Conservation and sustainable use of medicinal plants: problems, progress, and prospects. Chin med. 2016;11(1):37. https://doi.org/10.1186/s13020-016-0108-7.

21. Dey A, Nandy S, Mukherjee A, Modak BK. Sustainable utilization of medicinal plants and conservation strategies practiced by the aboriginals of Purulia district, India: a case study on therapeutics used against some tropical otorhinolaryngologic and ophthalmic disorders. Environ Dev Sustain. 2021;23(4):5576-613. https://doi.org/10.1007/s10668-020-00833-8.

22. Seixas C, Berkes F. Community-based enterprises: The significance of partnerships and institutional linkages. Int $\mathrm{J}$ of the Commons. 2009;4(1):183-212. http://doi.org/10.18352/ijc.133.

23. Kumar P, Shaunak I, Gambhir G, Dhiman K, Srivastava DK. Biotechnological Application of Meta-topolins as Highly Active Aromatic Cytokinins in Micropropagation of Medicinal Plants. Meta-topolin: A Growth Regulator for Plant Biotechnology and Agriculture. $2021 ; 241$. https://doi.org/10.1007/978-981-15-9046-7_17.

24. Roopashree S, Anitha J, Madhumathy P. Machine Learning Approach: Enriching the Knowledge of Ayurveda from Indian Medicinal Herbs. In Challenges and Applications of Data Analytics in Social Perspectives, IGI Global. 2021; 214-31. https://doi.org/10.4018/978-1-79982566-1.ch012. 
25. Jena S, Kumar G, Singh DK, Sethi AK. Herbs used in dentistry: Need of the new era. J of Prim Care Dent Oral Health. 2021;2(1):11. https://doi.org/10.4103/jpcdoh.jpcdoh_7_20.

26. Islam T, Magray JA, Zargar SA. Role of Herbs against COVID-19. Hospitality and Tourism Industry amid COVID-19 Pandemic,Eureka Publications. 2021; 409-417.

27. Chouhan D. Tulsi-The Medicine Excellent Health and Medicinal Remedy. J Adv Pharmacogn. 2021;1(2):26-34.

28. Hanumanthaiah P, Panari H, Chebte A, Haile A, Belachew G. Tulsi (Ocimum sanctum)-a myriad medicinal plant, secrets behind the innumerable benefits. Arabian J Medicinal Aromatic Plants. 2020;6(1):105-27. https://doi.org/10.48347/IMIST.PRSM/ajmap-v6i1.20401.

29. Upadhyay RK. Tulsi. A holy plant with high medicinal and therapeutic value. Int J of Green Pharm. 2017; 11(01).

30. Baildya N, Khan AA, Ghosh NN, Dutta T, Chattopadhyay AP. Screening of potential drug from Azadirachta indica (Neem) extracts for SARSCoV-2: An insight from molecular docking and MD-simulation studies. J Mol Struct. 2021;1227:129390. https://doi.org/10.1016/j.molstruc.2020.129390.

31. Shooriabi M. Effects of Allium sativum (Garlic) and Its Derivatives on Oral Diseases: A Narrative Review. J Res Dent Maxillofac Sci. 2021;6(1):36-44.

32. Ashfaq F, Ali Q, Haider MA, Hafeez MM, Malik A. Therapeutic activities of garlic constituent phytochemicals. Biol Clinical Sci Res J. 2021; 2021(1): e007-e007.

33. Syed QA, Rashid Z, Ahmad MH, Shukat R, Ishaq A, Muhammad N, Rahman HUU. Nutritional and therapeutic properties of fenugreek (Trigonellafoenum-graecum): a review. IntJl of Food Properties. 2020;23(1):1777-91. https://doi.org/10.1080/10942912.2020.1825482.

34. Promila SS, Devi P. Pharmacological potential of Tinosporacordifolia (Willd.) Miers ex hook. \&Thoms. (Giloy): A review. J Pharmacogn Phytochem. 2017; 6 (6): 1644-1647.

35. Verma DK, Kumar P, El-Shazly M. Unmasking the Many Faces of Giloy (TinosporacordifoliaL.): A Fresh Look on its Phytochemical and Medicinal Properties. Curr Pharm Des. 2020. https://doi.org/10.2174/1381612826666200625111530.

36. Selvamuthukumaran M. Amla (Indian Gooseberry): Characteristics, Therapeutic Potential, and Its Value Addition. In Asian Berries, CRC Press. 2020; 363-380. (eBook ISBN:9780429286476).

\section{Figures}

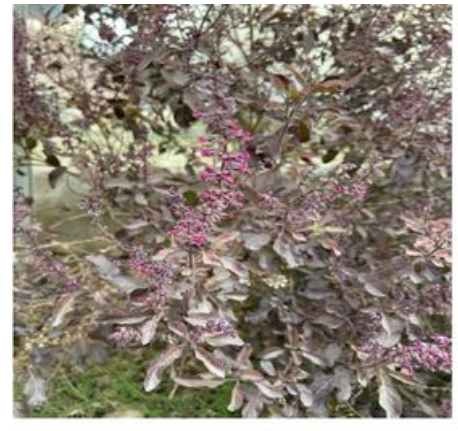

Ocimum Tenuiflorum

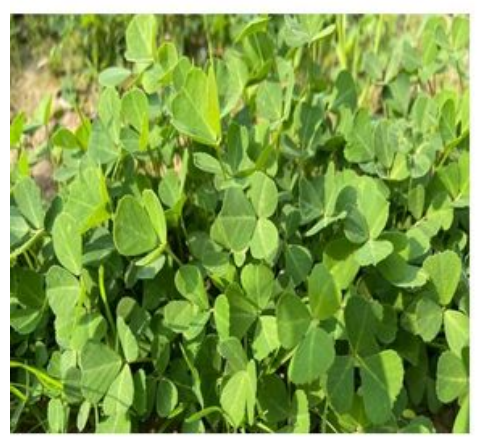

Trigonella foenum-graecum

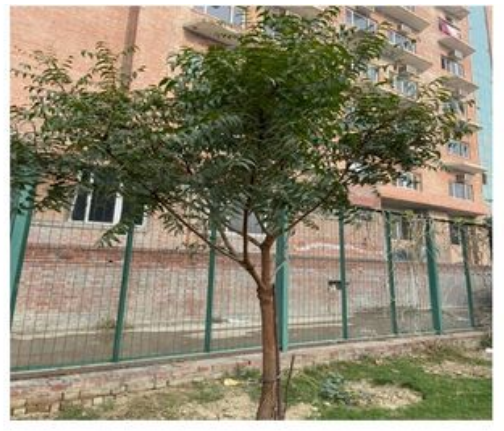

Azadirachta Indica

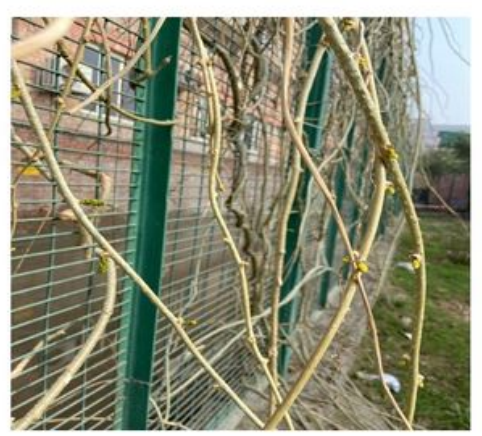

Tinospora cordifolia

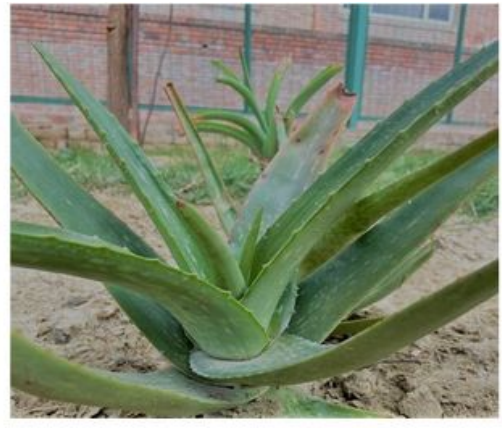

Aloe barbadensis

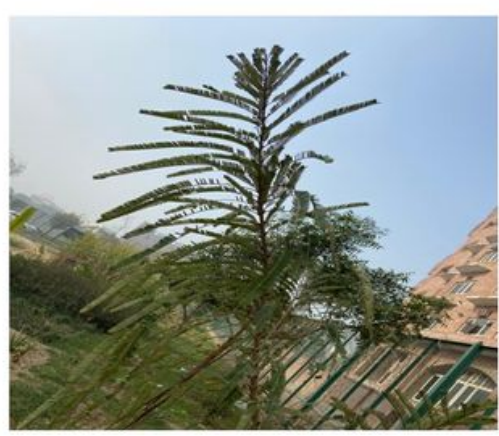

Plyllanthus emblica

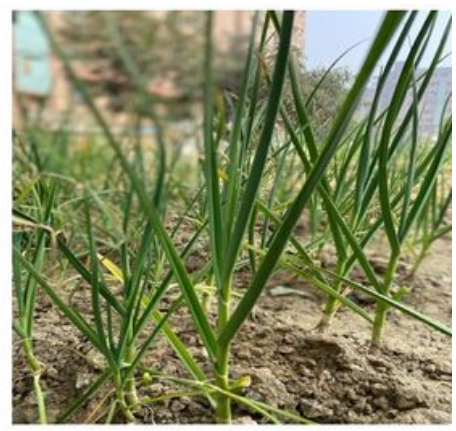

Allium sativum

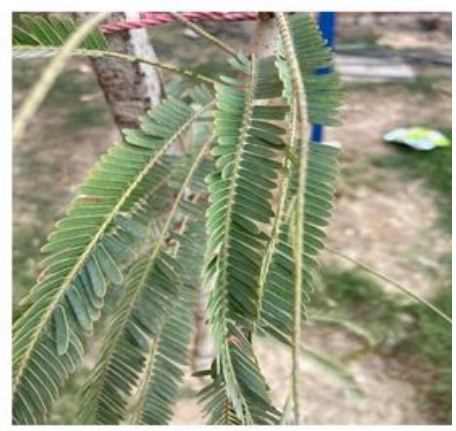

Phyllanthus emblica (focused Leaf view)

Figure 1

Medicinal plants growing in School of Agricultural Sciences, Sharda University, Greater Noida 


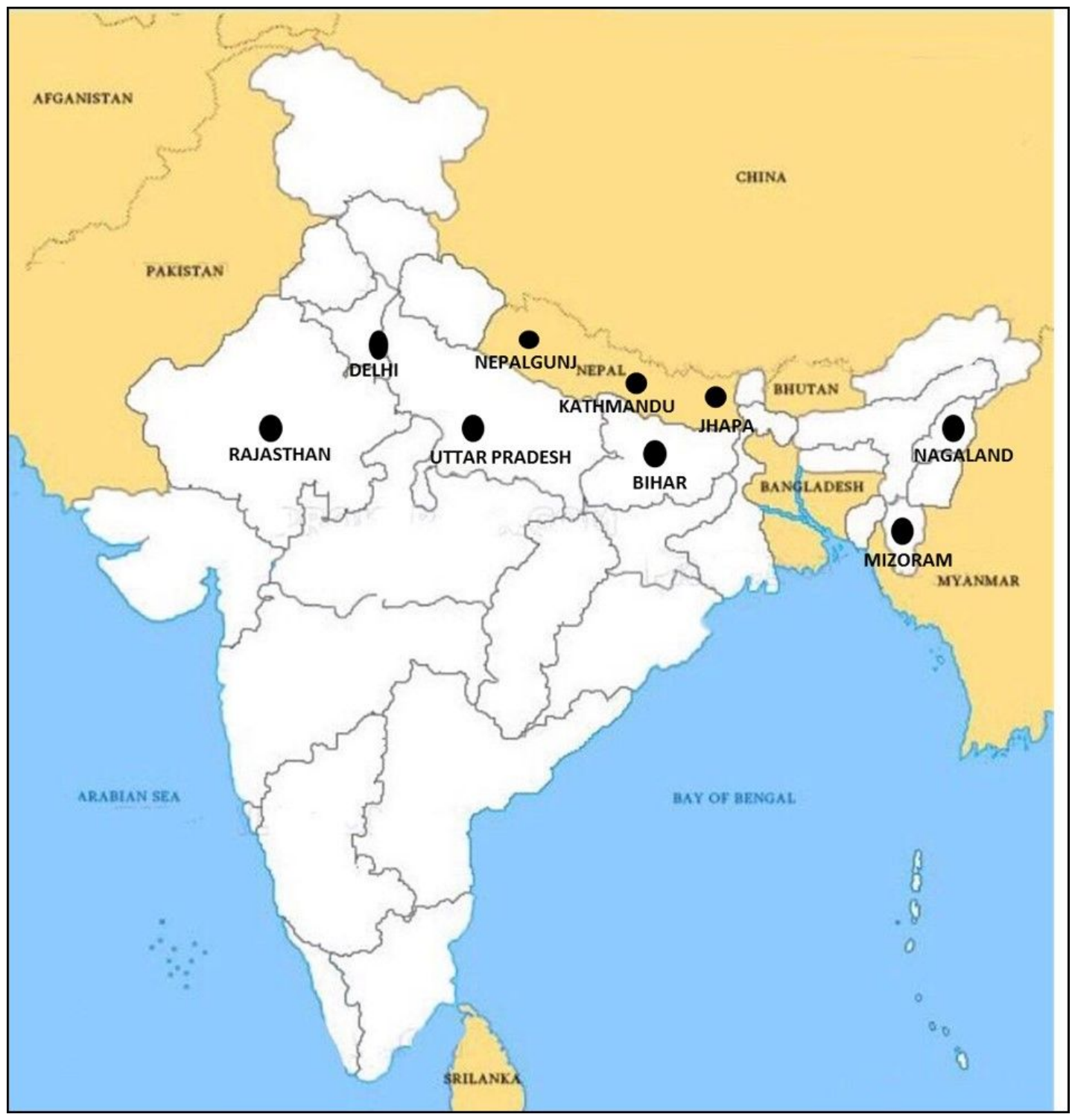

Figure 2

Representation of map showing selected location for present survey analysis.

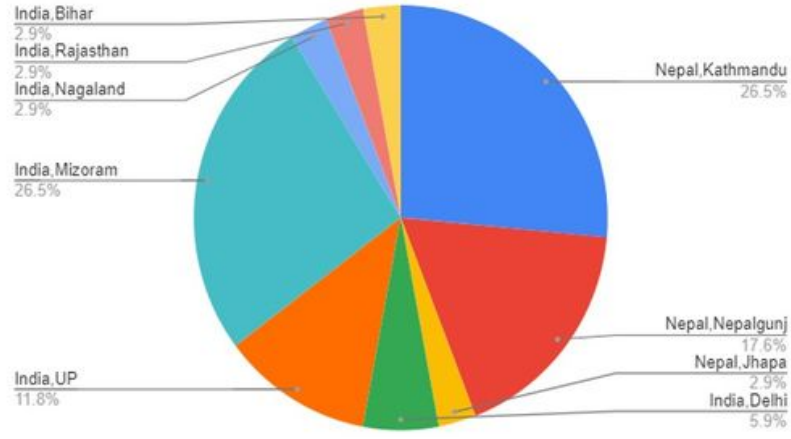

(A) Sample location and percentage of peoples

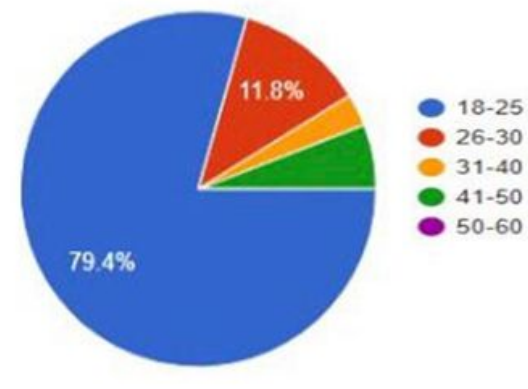

(B) Age Group

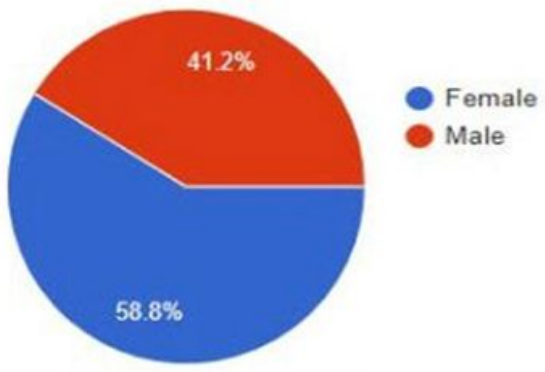

(C) Gender

Figure 3

Bar diagram showing sample location and percentage of peoples (A), Age group (B) and Gender (C) 

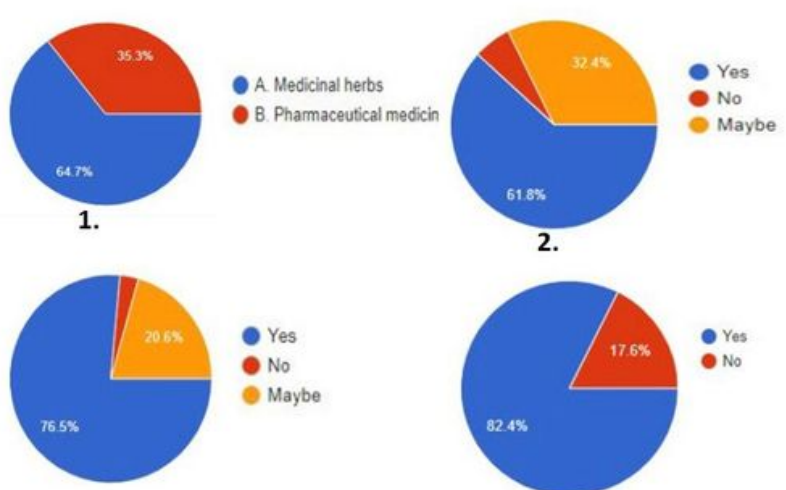

5.

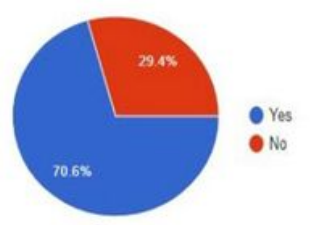

9.

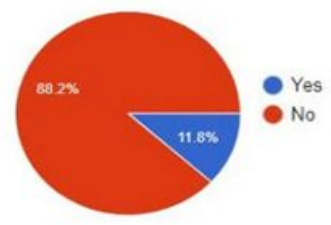

13.
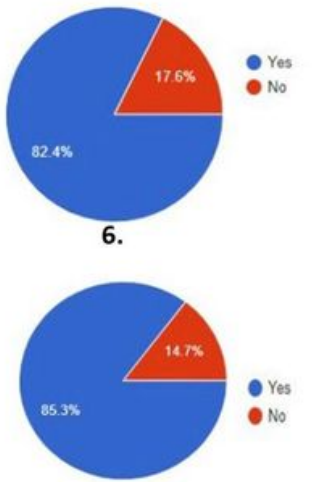

10.

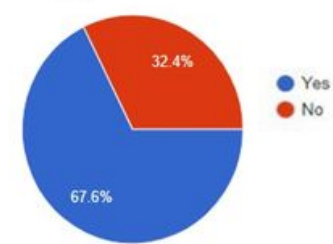

14.

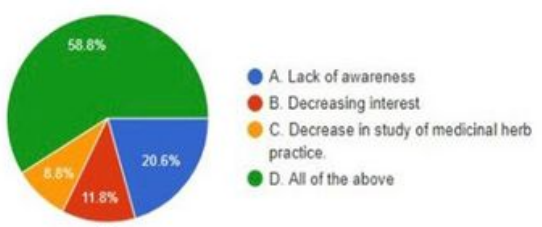

3.

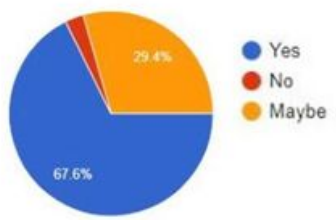

7.

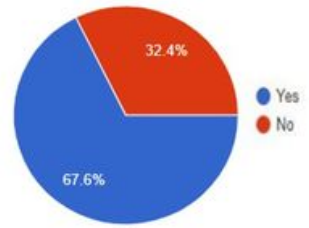

11.

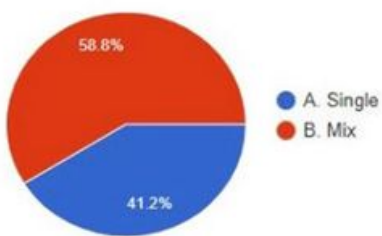

15.

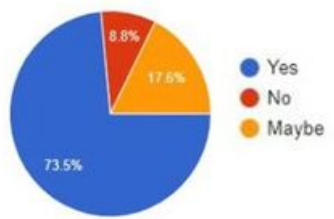

4.

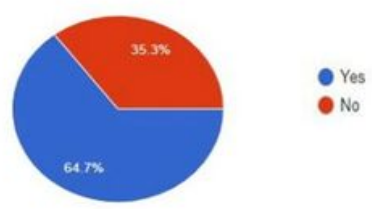

8.

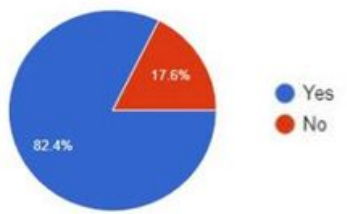

12.

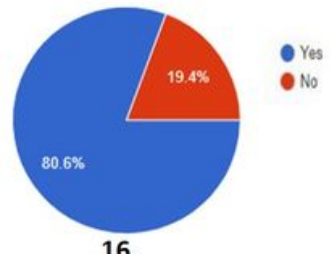

\section{Figure 4}

Bar diagram showing number of question from 1-16. (Detail questions has been explained in Table 2)

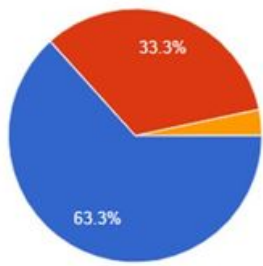

17.

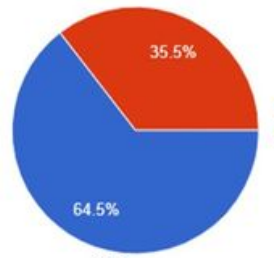

21.

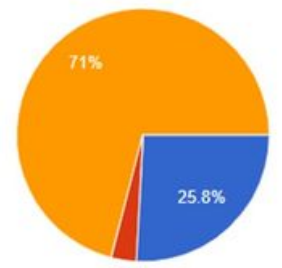

25.

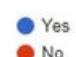$$
\text { Maybe }
$$

- Aloe Vera

- Pharmaceutical medicine

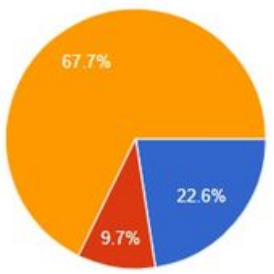

18.

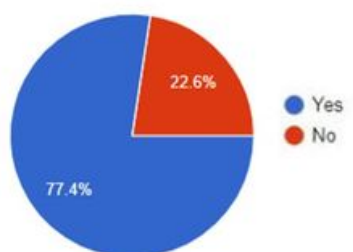

22.

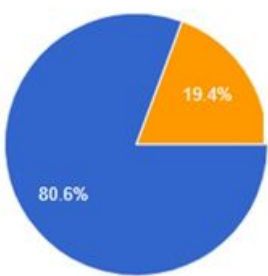

26.

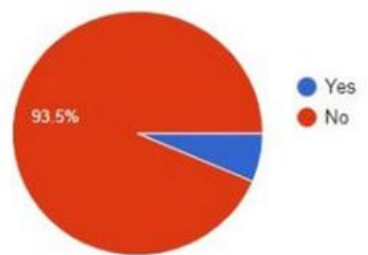

19.

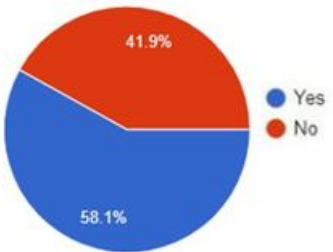

23.

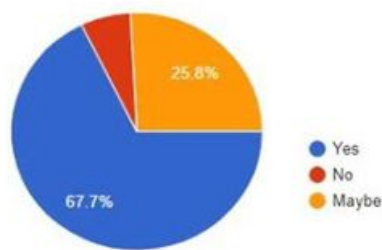

27.

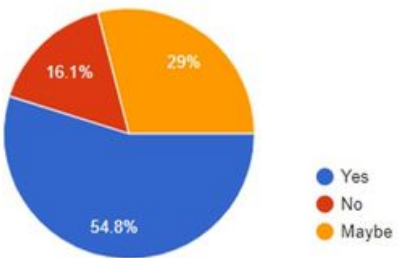

20.

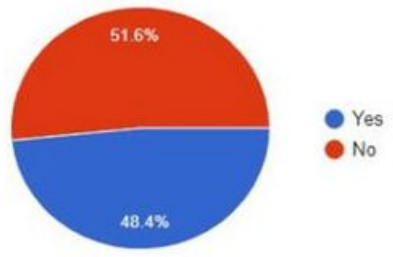

24.

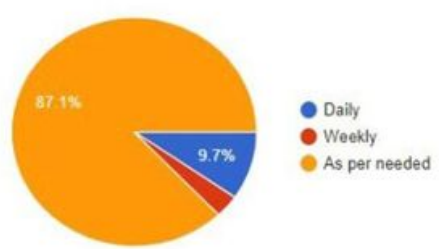

28.

Figure 5 
Bar diagram showing number of question from 17-28. (Detail questions has been explained in Table 1)

Page 17/17 